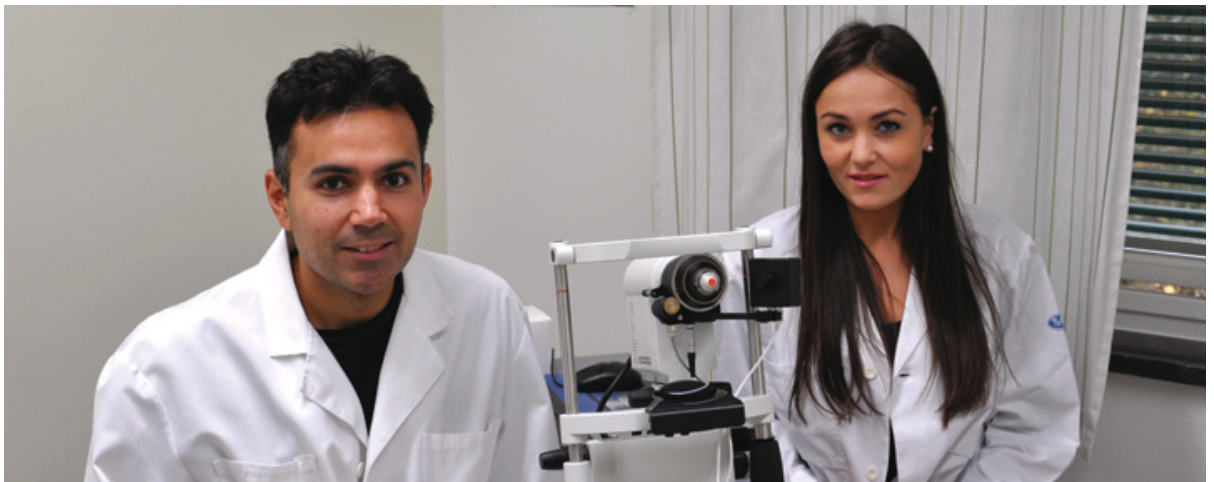

Sisteforfatter Neil Lagali og førsteforfatter Marlen Parissi med et in vivo-konfokalmikroskop. Foto: Monica Johnsson, Universitetssjukhuset i Linköping

\title{
Måling av nervefibertetthet i hornhinnen
}

\author{
Måling av nervefibrenes tetthet i hornhinnen kan være til hjelp ved \\ diagnostikk av alvorlige øyesykdommer. I en ny studie presenteres \\ normalverdier for nervefibertettheten.
}

Nervefibrene ligger over 300 ganger tettere i øyets hornhinne enn i huden, og sykdom i hornhinnen kan gi betydelige smerter. Hornhinnelidelser er en av de vanligste årsakene til blindhet $\mathrm{i}$ verden $\mathrm{i}$ dag.

Nervene i hornhinnen sørger for utskilling av cytokiner og nevrotransmittere som bidrar til å holde hornhinnen frisk. Ved flere hornhinnelidelser som kan føre til blindhet, blant annet keratokonus og aniridi, er antall nervefibre betydelig redusert. Det samme gjelder enkelte systemsykdommer, bl.a. diabetes mellitus. Måling av nervefibertetthet kan derfor tenkes å være til hjelp for diagnostikk og prognostikk. Til dette trengs en standardisert protokoll for måling og tolking av nervefibertetthet.

En nylig publisert studie er den hittil største der man har undersøkt tetthet av nervefibre i hornhinnen hos friske personer (1). Studien omfattet 106 friske personer i alderen 15-88 år. Disse ble rekruttert blant ledsagere til pasienter ved øyeavdelingen i Linköping, Sverige. De fikk en komplett oftalmologisk undersøkelse, inkludert laserskanning med in vivo-konfokalmikroskopi av den sentrale delen av hornhinnen. Nesten 900 bilder ble analysert for å fastsette nervefibertetthet $i$ den sentrale subbasale delen av hornhinnen. Gjennomsnittlig nervefibertetthet var 19,0 $\pm 4,5 \mathrm{~mm} / \mathrm{mm}^{2}$. Nervefibertettheten var uavhengig av kjønn, men negativt assosiert med alder, med en gjennomsnittlig reduksjon på $2-3 \%$ per tiår. Forfatterne presenterte også en ny metode som kan øke presisjonen og redusere tiden det tar å gjøre slike målinger.

- Vi håper våre funn kan brukes som referanseverdier for måling av nervefibertetthet i hornhinnen og på den måten bidra til at slike målinger kan bli et hjelpemiddel for diagnostikk av øyesykdommer, sier Marlen Parissi, som er førsteforfatter av artikkelen. Dette er hennes første publikasjon.

- Vi foreslår å ta i bruk automatiserte målemetoder for å gjøre analysen av nervefibertetthet mindre tidkrevende. I vår studie fant vi ingen forskjell i resultatene fra automatiserte analyser og resultatene fra analyser utført av mennesker, sier Parissi.

\section{Øyeforskning i flere land}

Studien er et resultat av et tett samarbeid mellom fagmiljøer i flere land, bl.a. Avdeling for medisinsk biokjemi, Oslo universitetssykehus, Tørreøyneklinikken i Oslo og forskere ved universitetene i Linköping, Sverige og Padova, Italia og Harvard Medical School, USA. Førsteforfatter Marlen Parissi er medisinstudent ved Universitetet i Oslo. Hun startet nylig sitt forskerlinjeår under veiledning av førsteamanuensis Neil Lagali og øyelege Tor Paaske Utheim, som siden 2010 har samarbeidet om flere innovasjonsprosjekter, bl.a. rask og presis computerassistert diagnostikk av øyesykdommer, sammen med professor Alfredo Ruggeri i Padova. De andre medforfatterne var Georgios Karanis, Stefan Randjelovic, Johan Germundsson og Enea Poletti.

\section{Matilde Risopatron Berg}

matilde.risopatron.berg@legeforeningen.no Tidsskriftet

\section{Litteratur}

1. Parissi M, Karanis G, Randjelovic S et al. Standardized baseline human corneal subbasal nerve density for clinical investigations with laser-scanning in vivo confocal microscopy. Invest Ophthalmol Vis Sci 2013; e-publisert 1.10.2013.
Ordforklaringer

Keratokonus: Progressiv fortynning av hornhinnen, der sentrale del buker fremover. I sjeldne tilfeller kan hornhinnen briste.

Aniridi: En arvelig sykdom som kjennetegnes ved blant annet fravær av regnbuehinnen og redusert syn

In vivo-konfokalmikroskopi: Mikroskop som gir mulighet for å ta bilder av svært høy oppløsning av de ytterste strukturene i kroppen, f.eks. hornhinnen og huden. 